\section{OPEN ACCESS}

Edited by:

Hans-Peter Mock

Leibniz Institute of Plant Genetics and

Crop Plant Research, Germany

Reviewed by:

Birte Svensson,

Technical University of Denmark,

Denmark

Robert Drant Willows,

Macquarie University, Australia

*Correspondence:

Robert Winkler,

Laboratory of Biochemical

and Instrumental Analysis,

Department of Biotechnology

and Biochemistry, Cinvestav Unidad Irapuato, Km. 9.6 Libramiento Norte,

Carretera Irapuato-León,

36821 Irapuato, Guanajuato, Mexico robert.winkler@ira.cinvestav.mx

Specialty section

This article was submitted to

Plant Proteomics,

a section of the journal

Frontiers in Plant Science

Received: 30 June 2015 Accepted: 13 August 2015

Published: 31 August 2015

Citation:

López-Castillo LM

López-Arciniega JAl,

Guerrero-Rangel $A$,

Valdés-Rodríguez $S$, Brieba $L G$, García-Lara S and Winkler R (2015) Identification of B6T173 (ZmPrx35) as the prevailing peroxidase in highly insect-resistant maize (Zea mays, p84C3) kernels by activity-directed purification. Front. Plant Sci. 6:670.doi: 10.3389/fp/s.2015.00670

\title{
Identification of B6T173 (ZmPrx35) as the prevailing peroxidase in highly insect-resistant maize (Zea mays, p84C3) kernels by activity-directed purification
}

Laura M. López-Castillo ${ }^{1,2}$, Janet A. I. López-Arciniega ${ }^{1}$, Armando Guerrero-Rangel $^{3}$,
Silvia Valdés-Rodríguez ${ }^{3}$, Luis G. Brieba ${ }^{2}$, Silverio Garcia-Lara ${ }^{4}$ and Robert Winkler ${ }^{1 *}$

${ }^{1}$ Laboratory of Biochemical and Instrumental Analysis, Department of Biotechnology and Biochemistry, Cinvestav Unidad Irapuato, Irapuato, Mexico, ${ }^{2}$ Laboratorio Nacional de Genómica para la Biodiversidad, Unidad de Genómica Avanzada del Centro de Investigación y de Estudios Avanzados - Instituto Politécnico Nacional, Irapuato, Mexico, ${ }^{3}$ Department of Biotechnology and Biochemistry, Cinvestav Unidad Irapuato, Irapuato, Mexico, ${ }^{4}$ Plant-Food Molecular Breeding Unit, Tecnologico de Monterrey, Monterrey, Mexico

Plant peroxidases (PODs) are involved in diverse physiological processes, including defense against pathogens and insects. Contrary to their biological importance, only very few plant PODs have been proven on protein level, because their low abundance makes them difficult to detect in standard proteomics work-flows. A statistically significant positive correlation between POD activity and post-harvest insect resistance has been found for maize (Zea mays, p84C3) kernels. In combining activitydirected protein purification, genomic and proteomic tools we found that protein B6T173 (ZmPrx35) is responsible for the majority of the POD activity of the kernel. We successfully produced recombinant ZmPrx35 protein in Escherichia coli and demonstrate both, in vitro activity and the presence of a haem (heme) cofactor of the enzyme. Our findings support the screening for insect resistant maize variants and the construction of genetically optimized maize plants.

Keywords: maize (Zea mays), insect resistance, peroxidase, activity-directed proteomics, low-abundance proteins, plant proteomics

\section{Introduction}

Post-harvest loss of maize due to insect pests is a serious problem and can reach up to $80 \%$ in tropical regions (Pingali and Pandey, 2001). E.g., the lowland tropics of Mexico suffer up to $100 \%$ kernel damage and 30\% weight loss during half a year of storage (Bergvinson, 2001). Mainly small stockholders are affected, since they are not able to invest in suitable infrastructure and materials to protect their products. Maize kernels can be protected from insect damage either mechanically, by the use of metal silos (Tefera et al., 2011) and hermetic storage bags (García-Lara et al., 2013), or chemically, employing insecticides (Dales and Golob, 1997). However, both strategies increase the production costs for the farmer. In addition, the use of agrochemicals is discussed and is controversial due to environmental and health hazards (Pedlowski et al., 2012). Therefore, innate insect-resistance for maize kernels would be an attractive trait for plant breeding (Bergvinson and García-Lara, 2004) 
Previous studies have shown a positive correlation between peroxidase (POD) activity and maize weevil (Sitophilus zeamais) resistance of maize kernels (García-Lara et al., 2007a; Winkler and García-Lara, 2010). In the UniProt ${ }^{1}$ database (Magrane and Consortium, 2011), more than 400 Zea mays proteins are tagged as PODs. Remarkably, experimental evidence on the protein level is reported for only three of them. All of those refer to the same study, describing guaiacol POD activities isolated from corn root plasma membranes (Mika and Lüthje, 2003). Even considering that more POD identifications might exist, which are not registered in the UniProt repository, a lack of biochemical knowledge about PODs is evident. PODs, classified as E.C.1.11.1.x, catalyze various oxidative reactions, employing peroxides ( $\mathrm{ROOH}$, mostly as $\mathrm{H}_{2} \mathrm{O}_{2}$ ) as electron acceptors (Fleischmann et al., 2004; Fawal et al., 2013). In plants, PODs participate in many physiological processes (for review see Hiraga et al., 2001), such as auxin metabolism (Lagrimini et al., 1997), lignination (Whetten et al., 1998), tolerance against osmotic stress (Amaya et al., 1999) and senescence (Abeles et al., 1988). Cell wall associated class III PODs are involved in the loosening and stiffening of cell walls during plant development. However, the detailed functions of individual PODs remain to be elucidated (Francoz et al., 2015).

Therefore, in a previous study we developed a proteomic work-flow, which permits the efficient screening for proteins with POD activity from 1D-SDS-PAGE gels (Winkler and GarcíaLara, 2010). However, in some cases a clear identification of the proteins responsible for the POD activity is hampered, since only partially separated protein fractions are studied.

With the 1D strategy, no classic POD was detected in extracts of the highly maize weevil resistant maize p84C3. Instead, an abundant protein of unknown function was identified: B4FFK9_MAIZE (UniProt accession code; Winkler and GarcíaLara, 2010). Consequently, we tested the POD activity of this protein after heterologous production in Escherichia coli (E. coli). Recombinant B4FFK9_MAIZE displayed neither POD activity nor the typical Soret peak of hemoproteins. This negative result indicated that the initial proteomic analysis was distorted by the low abundance of the active $\mathrm{POD}(\mathrm{s})$ relatively to other proteins in the kernel.

In order to achieve a reliable identification of the active POD in highly insect-resistant p84C3 maize kernels, we performed an activity-directed purification prior to the mass spectrometry based protein identification. Subsequently, we verified our results by amplification and cloning of the cDNA of interest, as well as recombinant production and biochemical studies of the putative POD.

\section{Materials and Methods}

\section{Maize Genotypes}

The open pollinated population p84 was developed at the International Maize and Wheat Improvement Center (CIMMYT) from twenty Caribbean accessions that possessed

${ }^{1}$ http://www.uniprot.org moderate resistance to the larger grain borer Prostephanus truncatus (Horn; García-Lara et al., 2004). For the proteomic analyses we chose the third selection cycle with incremented POD activity and insect resistance.

\section{D-GE, SDS-PAGE}

Non-reducing SDS-PAGE and POD activity staining were carried out as described previously (Winkler and García-Lara, 2010). In short, maize seeds were milled using a Mixer Mill MM301 (Retsch, Hann, Germany) during $20 \mathrm{~s}$ at $30 \mathrm{~Hz}$. Protein was extracted incubating $100 \mathrm{mg}$ of tissue in $600 \mu \mathrm{L}$ of $50 \mathrm{mM}$ sodium phosphate buffer pH 6.8 and analyzed in SDS-PAGE 10\%. The POD activity was detected after incubation with a solution of $20 \mathrm{mM}$ guaiacol in $50 \mathrm{mM}$ phosphate buffer $\mathrm{pH} 6.8$ and $3 \% \mathrm{H}_{2} \mathrm{O}_{2}$ for $30 \mathrm{~min}$. As a second staining step, the protein in the gel was fixed in $40 \%(v / v)$ ethanol and $10 \%(v / v)$ acetic acid for $1 \mathrm{~h}$ and stained with Brilliant Blue R250 0.1\% solution (Sigma-Aldrich, St. Louis, MO, USA).

\section{Two-Dimensional (2D) Gel Electrophoresis}

Two-dimensional gel electrophoresis was performed according to the method of Bjellqvist et al. (1982), and carried out as reported previously by our group (Mata-Gómez et al., 2012). However, the conditions were adjusted in order to prevent the loss of POD activity. In particular, boiling and reducing agents were eliminated from the procedure. Immobiline ${ }^{\mathrm{TM}}$ dry strips of $13 \mathrm{~cm}$ length (GE Healthcare, Uppsala, Sweden) were rehydrated $12 \mathrm{~h}$ at $20^{\circ} \mathrm{C}$ with non-reductive isoelectric focusing buffer (50 mM Tris- $\mathrm{HCl}$ buffer $\mathrm{pH}$ 6.8, 0.5\% ampholite, 2\% CHAPS and $0.0001 \%$ bromophenol blue), containing $150 \mu \mathrm{g}$ of protein. IEF was conducted with an Ettan IPGphor 3 (GE Healthcare, Uppsala, Sweden). Focusing of $\mathrm{pH}$ 6-11 strips was carried out as follows: $150 \mathrm{~V}$ for $1 \mathrm{~h}, 300 \mathrm{~V}$ for $1 \mathrm{~h}, 600 \mathrm{~V}$ for $1 \mathrm{~h}$ followed by $8,000 \mathrm{~V}$ in gradient for $0.5 \mathrm{~h}$ and finally $5,000 \mathrm{~V}$ until reaching $26,000 \mathrm{Vh}$. For the $\mathrm{pH} 4-7$ strips, the focusing was performed $250 \mathrm{~V}$ for $1 \mathrm{~h}, 500 \mathrm{~V}$ for $0.5 \mathrm{~h}$, followed by $1,000 \mathrm{~V}$ for $0.5 \mathrm{~h}$ and finally $8,000 \mathrm{~V}$ to reach $12,000 \mathrm{Vh}$. After focusing, the gels were equilibrated twice for $15 \mathrm{~min}$ in a solution containing $6 \mathrm{M}$ urea, 30\% $w / v$ glycerol, $2 \% \mathrm{w} / \mathrm{v}$ SDS and $50 \mathrm{mM}$ Tris- $\mathrm{HCl}$ buffer, $\mathrm{pH}$ 8.8. For the second dimension, the proteins were separated on $12 \%$ SDS polyacrylamide gels. The POD activity was observed incubating the gels with a solution of $20 \mathrm{mM}$ guaiacol in $50 \mathrm{mM}$ phosphate buffer $\mathrm{pH} 6.8$ and $3 \% \mathrm{H}_{2} \mathrm{O}_{2}$ for $30 \mathrm{~min}$. The complete profile of protein spots was visualized using $0.1 \%$ Brilliant blue R250 (Sigma-Aldrich, USA).

\section{Densitometric Analysis}

For the quantification of the POD activity on 2D gels, an image analysis was performed by using the plugin Yawi-2D of the free Software ImageJ 1.47a. For further spot intensity determination, performed by the comparison of the integrals of color density of each spot, the original image was converted to an eight bitgrayscale image with 300 dpi resolution.

\section{In-Gel Digestion of Protein Bands}

For in-gel digestion of protein bands, the Shevchenko protocol (Shevchenko et al., 1996, 2006) was slightly modified, as described 
previously (Winkler and García-Lara, 2010). After the SDSPAGE, the POD active spots were sliced from the gel and chopped into cubes with about $1 \mathrm{~mm}$ of edge length. The cubes were transferred to vials and washed with a 1:1 $(v / v)$ solution of $125 \mathrm{mM}$ ammonium bicarbonate and acetonitrile (ACN) until complete discolouration. The reduction and alkylation steps were performed by incubation with $10 \mathrm{mM}$ DTT and $55 \mathrm{mM}$ IAA. The gel pieces were rinsed with $\mathrm{ACN}$, then the shrunken gel pieces were dried in a vacuum centrifuge. For the protein digestion, the dry gel pieces were re-hydrated in a $50 \mathrm{mM}$ ammonium bicarbonate solution containing $10 \mathrm{ng} / \mathrm{L}$ trypsin (PROMEGA, Madison, WI, USA) and incubated overnight at $37^{\circ} \mathrm{C}$. After tryptic digestion, the peptides could be extracted by shaking for 15 min with a $1: 2(v / v)$ solution of $5 \%$ formic acid/ACN at $37^{\circ} \mathrm{C}$. The supernatant was transferred to a new tube and dried in a vacuum centrifuge. Prior to LC-MS/MS analysis, the peptides were dissolved in $20 \mu \mathrm{L}$ of $0.1 \%(v / v)$ formic acid.

\section{Nanoflow LC-MS/MS}

All experiments were performed on a nanoAcquity nanoflow liquid chromatography (LC) system (Waters, Milford, MA, USA), coupled to a linear ion trap LTQ Velos mass spectrometer (Thermo Fisher Scientific, Bremen, Germany), equipped with a nano electrospray ion source. Solvent A consisted of $0.1 \%$ formic acid and solvent B of $100 \%$ ACN with $0.1 \%$ formic acid. Three micro liter of tryptically digested proteins were bound to a precolumn (Symmetry ${ }^{\circledR}$ C18, $5 \mu \mathrm{m}, 180 \mu \mathrm{m} \times 20 \mathrm{~mm}$, Waters). Subsequently, the flow was then switched to a $10 \mathrm{~cm}$ capillary UPLC column (100 $\mu \mathrm{m}$ ID BEH-C18 $1.7 \mu \mathrm{m}$ particle size). The column temperature was controlled at $35^{\circ} \mathrm{C}$. The peptides were separated by a $60 \mathrm{~min}$ gradient method at a flow rate of $400 \mathrm{~nL} / \mathrm{min}$. The gradient was programmed as follows: $3-50 \%$ solvent B (over $30 \mathrm{~min}$ ), $50-85 \%$ B (over $1 \mathrm{~min}$ ), $85 \%$ B (for $7 \mathrm{~min}$ ) and $3 \% \mathrm{~B}$ (over $22 \mathrm{~min}$ ). The peptides were eluted into the mass spectrometer nano electrospray source through a standard coated silica tip (NewObjective, Woburn, MA, USA). The mass spectrometer was operated in data-dependent acquisition mode in order to automatically alternate between full scan (400-2000 $\mathrm{m} / z$ ) and subsequent CID and PQD MS/MS scans in the linear ion trap. CID was performed using helium as collision gas at a normalized collision energy of $40 \%$ and $10 \mathrm{~ms}$ activation time. Data acquisition was controlled by Xcalibur 2.0.7 software (Thermo Fisher Scientific).

\section{Recombinant B4FFK9 Production}

For the recombinant production of B4FFK9 protein, a synthetic and codon- optimized version of the gene was designed (GenScript, Piscataway, NJ, USA). This gene was cloned into the pGEX-6P-1 vector (GE Healthcare, Uppsala, Sweden), between the restriction sites BamHI and EcoRI. The protein production was performed in the E. coli BL21 (DE3) Rosetta gami strain, using $0.5 \mathrm{mM}$ IPTG as inductor and $1 \mathrm{mM}$ 5-aminolevulinic acid (ALA, SIGMA-Aldrich, St. Louis, MO, USA) as cofactor supply. The induction was performed at $16^{\circ} \mathrm{C}$ during $16 \mathrm{~h}$. After the incubation, the bacterial pellet was recovered and resuspended in $25 \mathrm{mM}$ Tris-HCl, pH 7.0, buffer with $100 \mathrm{mM}$ $\mathrm{NaCl}$. The protein was purified with a standard GST purification procedure, using a Glutathione Sepharose column $(16 \times 25 \mathrm{~mm}$.; GE Healthcare, Uppsala, Sweden), and according to the column manual. Imidazole was removed from the protein fractions by dialysis. The purified protein was cleaved from the GST-tag using a recombinant PreScission Protease, and tested for POD activity. POD activity was tested by incubating $20 \mu \mathrm{L}$ of protein solution in $230 \mu \mathrm{L}$ of reaction buffer $(50 \mathrm{mM}$ sodium phosphate $\mathrm{pH} 6.8$, $20 \mathrm{mM}$ guaiacol, $0.3 \% \mathrm{H}_{2} \mathrm{O}_{2}$ ).

\section{Partial Purification of Native Peroxidases from Maize Seeds}

Native PODs were partially purified in a three-step strategy: $50 \mathrm{~g}$ of milled maize seed tissue were homogenized with $250 \mathrm{~mL}$ of $25 \mathrm{mM}$ Tris- $\mathrm{HCl}, \mathrm{pH} 7.0$, then incubated at $4^{\circ} \mathrm{C}$ during $1 \mathrm{~h}$ and subsequently centrifuged at $27,150 \mathrm{~g}$ for $30 \mathrm{~min}$. The supernatant was collected, filtered and then loaded on a Macro-Prep High $S$ Support column $(1.5 \times 14.1 \mathrm{~cm}$; Bio-Rad, Hercules, CA, USA $)$. Protein was eluted with a linear gradient from 0 to $1 \mathrm{M} \mathrm{NaCl}$. A POD activity test was performed for all collected fractions as described above. The fractions with POD activity were then affinity-separated using a Concanavalin A column $(0.8 \times 4 \mathrm{~cm}$.; SIGMA, USA) and tested again for POD activity. Active fractions were dialysed against $25 \mathrm{mM}$ Tris $\mathrm{pH} 7.0$ and centrifuged at $20,400 \mathrm{~g}$ for $5 \mathrm{~min}$. The supernatant was collected and purified using a $5 \mathrm{~mL}$ "Macro-Prep High Q Support" column (BioRad, Hercules, CA, USA). The flow-through was collected and concentrated using ultrafiltration membranes (10 kDa MWCO, Millipore, USA). The band with POD activity was separated by SDS-PAGE and prepared for nanoESI-LC-MS/MS.

\section{Maize RNA Extraction and cDNA Preparation}

RNA was extracted from p84C3 maize seeds according to the protocol of Wang et al. (2012). cDNA was prepared using the SuperScript III Reverse Transcriptase (Invitrogen, Carlsbad, CA, USA) and a Poly-dT primer, following the manufacturer indications for GC-rich genes. The reaction mixture was heated at $65^{\circ} \mathrm{C}$ for $5 \mathrm{~min}$. The elongation was carried out with a temperature of $50^{\circ} \mathrm{C}$.

\section{ZmPrx35 Gene Constructs}

For the recombinant production of B6T173 (ZmPrx35) protein, the respective gene was amplified from p84C3 maize cDNA using an N-terminal primer including a NdeI restriction site at the start codon: 5'-GACGACGACATATGAGCTCGACGTGGC TGGC- $3^{\prime}$; and a C-terminal primer including a BamHI restriction site downstream of the stop codon: $5^{\prime}$-TCGTCGTC GGATCCCTAGTAGTGTGGGTTGACGA-3'. The amplification was performed considering the high GC content of the gene, using the Kapa HiFi Polymerase (Kapa Biosystems, Wilmington, MA, USA). For PCR, the following conditions were used: after denaturation at $95^{\circ} \mathrm{C}$ for $5 \mathrm{~min}, 35$ cycles were carried out with: $20 \mathrm{~s}$ of denaturation at $98^{\circ} \mathrm{C}, 15 \mathrm{~s}$ of annealing at $57.5^{\circ} \mathrm{C}$ and $1 \mathrm{~min}$ of extension at $72^{\circ} \mathrm{C}$. Finally, a denaturation temperature of $72^{\circ} \mathrm{C}$ was held for $10 \mathrm{~min}$. The amplicon was cloned into different vectors for testing protein production: $\mathrm{pET19b}$, pET28b, and pMALc5x, using the restriction sites NdeI and BamHI. 


\section{Recombinant B6T173 (ZmPrx35) Production}

Protein production for the constructs cloned into the pET19b and the pMALc5x vectors was performed using the E. coli BL21 (DE3) Rosetta gami strain. For the construct cloned into the pET28b vector, the E. coli BL21 (DE3) Rosetta II start was used. In both cases, the cultures were grown to an $\mathrm{OD}_{600}$ of 0.8 before inducing the gene expression with $0.5 \mathrm{mM}$ IPTG. $1 \mathrm{mM}$ ALA, $1 \mathrm{mM} \mathrm{FeSO}_{4}$ and $1 \mathrm{mM} \mathrm{CaCl}_{2}$ were supplemented as cofactors. The induction was carried out at $16^{\circ} \mathrm{C}$ for $16 \mathrm{~h}$. The bacterial pellet was recovered and re-suspended in $25 \mathrm{mM}$ Tris- $\mathrm{HCl} \mathrm{pH}$ 7.0, $2 \mathrm{M} \mathrm{NaCl}$ buffer. The protein was purified in four steps: (1) A standard "His-Tag" affinity chromatography procedure, using a His-Trap FF column $(16 \times 25 \mathrm{~mm}$; GE Healthcare, Uppsala, Sweden); (2) and (3) two ionic-exchange purification steps, using columns Q $(0.8 \times 4 \mathrm{~cm}$, High Q support, Bio Rad, USA $)$ and S $(0.8 \times 4 \mathrm{~cm}$, High S support, Bio Rad, Saint Louis, MO, USA), and (4) a size-exclusion chromatography on a Superdex 75 Column $(10 \times 300 \mathrm{~mm}$; GE Healthcare, Uppsala, Sweden). The purified fractions were concentrated by ultrafiltration.

\section{Optimized B6T173 (ZmPrx35) Production}

For increasing yield and purity of the recombinant ZmPrx35 protein, an optimized version of the gene was designed and divided into two gBlocks (Integrated DNA Technologies, USA). The gBlocks were cloned independently into the pJET1.2 vector (Thermo Scientific, USA), and then fused using a previously described protocol (Heckman and Pease, 2007). The assembled gene was cloned into the vectors pET32a and pET28b (Novagen), between the restriction sites EcoRI and Xho I. The protein production was performed in the E. coli BL21 (DE3) Rosetta gami strain, using $1 \mathrm{mM}$ IPTG as inductor and supplementing the culture media with $1 \mathrm{mM}$ ALA and $1 \mathrm{mM} \mathrm{FeSO}_{4}$ as cofactors. The induction was carried out at $16^{\circ} \mathrm{C}$ for $16 \mathrm{~h}$. After the incubation, the bacterial pellet was recovered and re-suspended in a $25 \mathrm{mM}$ Tris- $\mathrm{HCl} \mathrm{pH} 7.0,150 \mathrm{mM} \mathrm{NaCl}$ buffer. For the purification assay, the standard "His-Tag" purification procedure was tested, using a His-Trap FF column $(16 \times 25 \mathrm{~mm}$, GE Healthcare, Uppsala, Sweden).

\section{Identification of the Haem Cofactor}

The identification of the haem group was achieved by two different strategies. The first strategy relied on a spectrophotometrical scanning from 250 to $800 \mathrm{~nm}$, in order to detect the Soret peak of absorbance, which is expected between 400 and 500 nm (Dalton et al., 1996; Shannon et al., 1966; Ray et al., 2012).

The second strategy was a luminol-based test for iron detection. This assay was performed as described by Högbom et al. (2005). Two different conditions have been tested: the protein in native state, and the unfolded (denatured) protein. For the protein in native state, $1 \mu \mathrm{g}$ of protein were loaded on a black, half area, 96-well plate (Corning, NY, USA), followed by the addition of $40 \mu \mathrm{L}$ of $1 \mathrm{M}$ Tris- $\mathrm{HCl} \mathrm{pH} 7.0$ and $100 \mu \mathrm{L}$ of the reaction buffer ( $11 \mathrm{mM}$ luminol, $500 \mathrm{mM} \mathrm{Na} 2 \mathrm{CO} 3,230 \mathrm{mM}$ $\mathrm{H}_{2} \mathrm{O}_{2}$ ). For the unfolded protein, $40 \mu \mathrm{L}$ of $8 \mathrm{M}$ urea were loaded to the plate, followed for the addition of the same amounts of protein and reaction buffer described above. All the buffer solutions were treated with Chelex 100 (Sigma, St. Louis, MO,
USA). The luminescence was detected by exposing a CL-Xposure Film (Thermo Scientific, Rockford, IL, USA) to the wells of the plate with the reaction mixture.

\section{Protein Identification and Hit Validation}

Employing a target-decoy strategy (Elias and Gygi, 2007), concatenated databases were generated. For the native maize protein identification, the decoy database contained all Z. mays entries of the NCBI protein database ${ }^{2}$ (download 13/04/24). For recombinantly produced protein, the decoy database included all E. coli BL21(DE3) entries ( ${ }^{2}$ download 15/04/27) and the B6T173 entry of $Z$. mays. Generation of databases was performed by using the software FastaTools 0.9 (David Ovelleiro, CSIC-UAB). Raw spectra were converted to *.mzXML and *.mgf files using the ProteoWizard toolkit version 3.0.3364 (Chambers et al., 2012).

Data were analyzed by using two different proteomic platforms. In the first strategy, the data were uploaded to a local LabKey 12.3 server (Rauch et al., 2006) and subsequently analyzed with a pipeline employing the bundled versions of X!Tandem (Craig and Beavis, 2004), PeptideProphet (Keller et al., 2002) and ProteinProphet (Nesvizhskii et al., 2003). For the ProteinProphet, a minimum protein probability of 0.95 was set.

In the second strategy, we transformed the Thermo raw data with to ProteoWizard toolkit to *.mgf and performed an analysis with the PeptideShaker suite v0.38.1 (Barsnes et al., 2011). A PeptideShaker compatible target-decoy database was built from the UniProt Z. mays protein sequences ('un-reviewed') and submitted to the bundled SearchGUI tool (Vaudel et al., 2011). As search engines we employed in this analysis both possible options, OMSSA version 2.1.9 win32 (Geer et al., 2004) and X!Tandem version 13.2.1.1 (Craig and Beavis, 2004).

We re-processed the mass spectrometry data with the TransProteomic Pipeline $4.8 .0^{3}$ (Deutsch et al., 2015) on MASSyPup (Winkler, 2014). Raw files and results were deposited to the ProteomeXchange Consortium ${ }^{4}$ (Vizcaíno et al., 2014) via the PRIDE partner repository ${ }^{5}$. The data may be accessed with the login reviewer64284@ebi.ac.uk and password Td4Dkr5d, using the dataset identifier PXD002166 (after publication of the article, the data will be public).

\section{BLAST Searches}

BLAST searches were performed using BLASTP (Altschul et al., 1997) on the UniProt webpage ${ }^{6}$, searching the UniProtKB (Magrane and Consortium, 2011) database with the standard parameters.

\section{Maize eFP Browser}

The expression pattern of the identified protein was investigated with the Maize eFP Browser ${ }^{7}$ (Winter et al., 2007; Sekhon et al., 2011).

\footnotetext{
${ }^{2}$ http://www.ncbi.nlm.nih.gov/protein/

${ }^{3}$ http://sourceforge.net/p/sashimi/wiki/Home/

${ }^{4} \mathrm{http}$ ://www.proteomexchange.org/

${ }^{5}$ http://www.ebi.ac.uk/pride/archive/

${ }^{6}$ http://www.uniprot.org/blast/

${ }^{7}$ http://www.bar.utoronto.ca/
} 


\section{Results and Discussion}

\section{Proteins with Peroxidase Activity in 2D Gel Analysis}

Separation of proteins from p84C3 maize kernel extracts with 2D electrophoresis and subsequent staining for POD activity revealed six defined active spots (Figure 1A). Densitometric analysis suggests that spot 1 accounts for about $80 \%$ of the total activity (see Table 1). This is astonishing because more than 400 PODs are suspected for Z. mays according to the UniProt ${ }^{8}$ database. Spot 1 exhibits an apparent MW of $31 \mathrm{kDa}$ and a $\mathrm{pI}$ of 9.5. Spots 4-6 display the same apparent molecular weight on the gel and thus might be isoforms of the protein represented by spot 1. Spots 2 and 3 displayed an apparent MW of $45 \mathrm{kDa}$ and $\mathrm{pI}$ of 9.3 and 9.5, respectively. After subsequent Coomassie staining of the gel, only one protein spot was still visible (Figure 1B). This spot corresponds to the Spot 1 of the guaiacol- $\mathrm{H}_{2} \mathrm{O}_{2}$ staining (Figure 1A). The protein of this spot was sliced from the gel and subjected to nanoLC-MS/MS analysis.

Six proteins with more than two identified peptides were found in spot 1 by using PeptideShaker (see Table 2). The identification of various proteins in a presumably separated spot is not uncommon (Gupta et al., 2015), considering the high sensitivity of nanoLC-MS/MS and presence of highly abundant proteins, which contribute to the background. Ten validated peptides belong to Lactoylglutathione lyases. Further, late embryogenesis abundant protein D-34 was identified, as well as two isoforms of embryonic protein DC-8. None of

${ }^{8} \mathrm{http} / / /$ www.uniprot.org

TABLE 1 | Densitometric evaluation of peroxidase activity in 2D gel analysis.

\begin{tabular}{ll}
\hline Spot & \% of total activity \\
\hline 1 & 80.6 \\
2 & 3.12 \\
3 & 3.78 \\
4 & 3.34 \\
5 & 6.89 \\
6 & 2.24
\end{tabular}

those proteins can explain the POD activity. Two identified proteins are not annotated in the UniProt database and were submitted to BLAST searches. The UniProt protein sequences K7VEA3 and K7VM99 are isoforms and show a 66-68\% identity with Uniprot entry K4F957, a late embryogenesis abundant protein from Oryza sativa subsp. japonica (Rice). B4FFK9 displays $81 \%$ identity with Uniprot entry Q94J20, a lipoprotein-like Oryza sativa subsp. japonica (Rice) and $63 \%$ identity with the secreted $Z$. mays (Maize) proteins B6UI56 and K7V532. B4FFK9 corresponds to the accessions GRMZM2G043521_T01 and GRMZM2G043521_P01 in the maize sequence database ${ }^{9}$. Analysis of the expression pattern in the eFP Browser reveals a high abundance of the transcript GRMZM2G043521_T01 in the embryonic tissue during the last phase of embryogenesis, but it is absent in any other maize tissue or in other phases of plant development (Supplementary Figure S2), which suggests a specialized role for the maize kernel.

\section{In Vitro Production of B4FFK9 in E. coli}

From the 2D gel analysis and subsequent protein identification, as well as considering the expression profile, B4FFK9 was the most likely POD protein candidate. Additionally, local sequence similarity with POD motifs could indicate a novel POD type (Winkler and García-Lara, 2010). Thus, we tried a recombinant production of the protein in E. coli, as described in the methods part. The features of the purification buffers, near to neutral conditions, were designed according to the results of the $2 \mathrm{D}$ analysis (Figure 1), where the most active POD exhibited a pI near 9.5. Strong protein production was observable (Supplementary Figure S1B), but no POD activity could be detected (Supplementary Figure S1A). UV-VIS spectra did not show the expected Soret-band features (data not shown), indicating the absence of a haem cofactor. Suspecting incomplete cofactor loading, we supplemented the protein production with 5-ALA. But in none of the experiments we detected active protein.

Currently, plant PODs for industrial or laboratory use are either extracted from biological material or produced in vitro in cell cultures (González-Rábade et al., 2012). In

${ }^{9}$ http://www.maizesequence.org

TABLE 2 | NanoESI-LC-MS/MS based identification of proteins from 2D gel, spot 1, after POD activity staining (Data analysis with LabKey).

\begin{tabular}{|c|c|c|c|c|c|c|c|}
\hline Hit & Protein group & Inference class & Description & $\begin{array}{l}\text { Sequence } \\
\text { coverage [\%] }\end{array}$ & $\begin{array}{l}\text { \#Validated } \\
\text { peptides }\end{array}$ & $\begin{array}{l}\text { \#Validated } \\
\text { spectra }\end{array}$ & $\begin{array}{l}\text { Theoretical } \\
\text { MW [kDa] }\end{array}$ \\
\hline 1 & В6TPH0, С0РК05 & Unrelated proteins & Lactoylglutathione lyase & 21.3 & 10 & 22 & 35.1 \\
\hline 3 & B6SGN7 & Single protein & Embryonic protein DC-8 & 16.1 & 6 & 12 & 32.3 \\
\hline 4 & B4FFK9 & Single protein & $\begin{array}{l}\text { Uncharacterized protein/Lipoprotein }{ }^{1} / \\
\text { Secreted protein }\end{array}$ & 19.0 & 5 & 6 & 27.7 \\
\hline 6 & K7VEA3, K7VM99 & Isoforms & $\begin{array}{l}\text { Uncharacterized protein/ Late } \\
\text { embryogenesis abundant protein }{ }^{1}\end{array}$ & 12.5 & 2 & 2 & 28.4 \\
\hline
\end{tabular}

${ }^{1}$ Evaluated by BLASTP. 


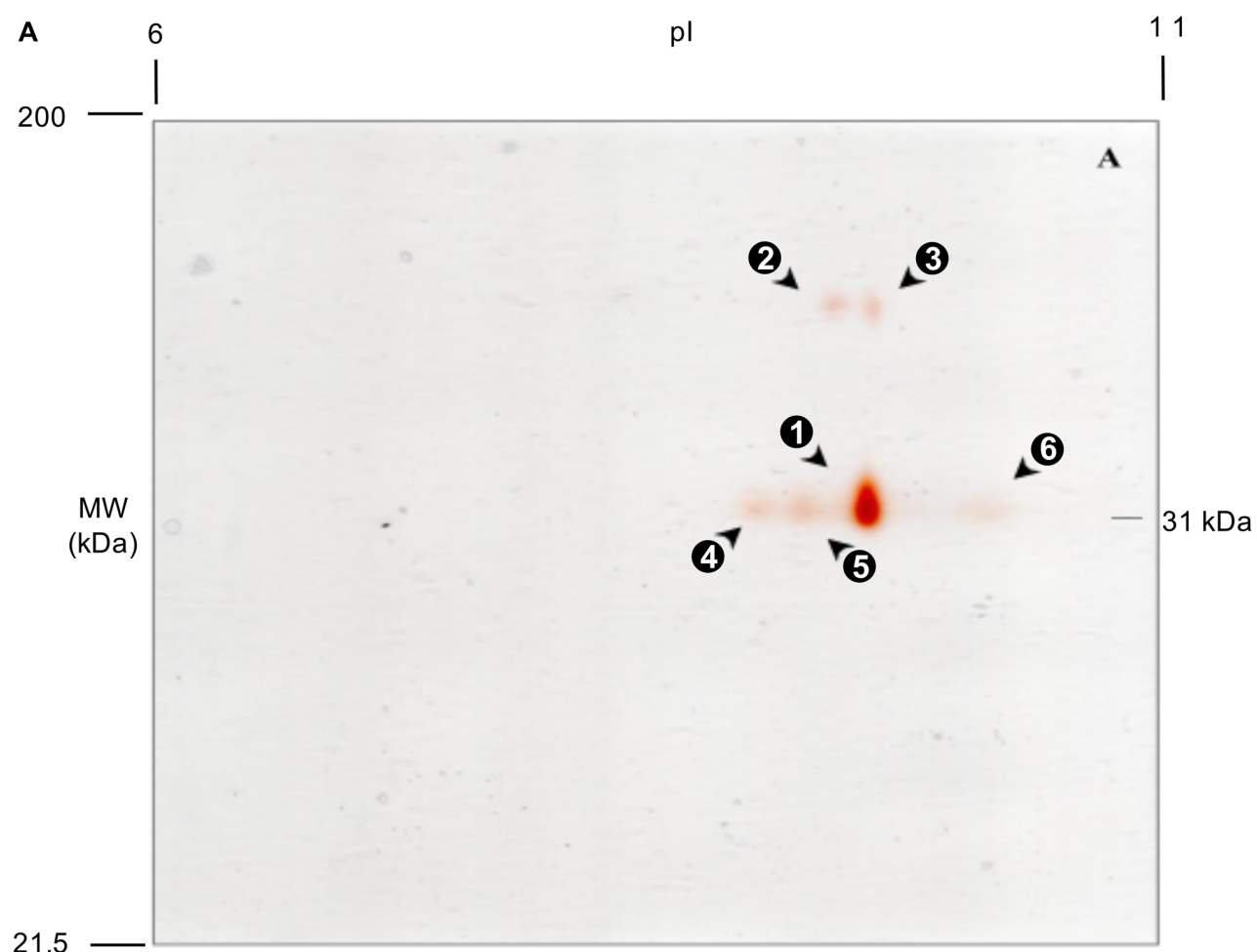

B

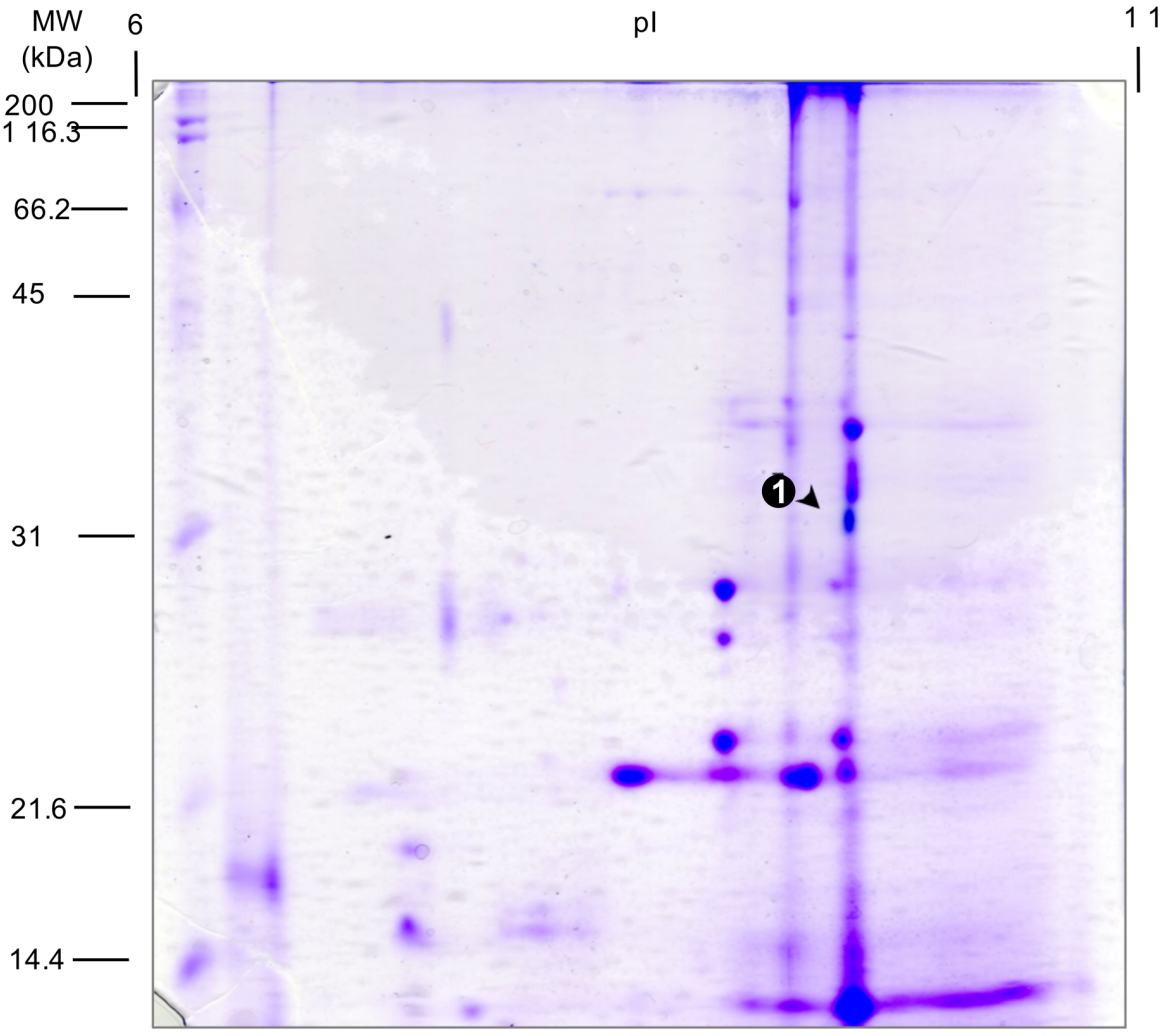

FIGURE 1 | 2D Analysis of peroxidase (POD) activity from p84C3 maize kernels. (A) Guaiacol- $\mathrm{H}_{2} \mathrm{O}_{2}$ staining. (B) Sequential staining (guaiacol- $\mathrm{H}_{2} \mathrm{O}_{2}+$ Coomassie R-250). Arrows point to the spots with $\mathrm{POD}$ activity. 


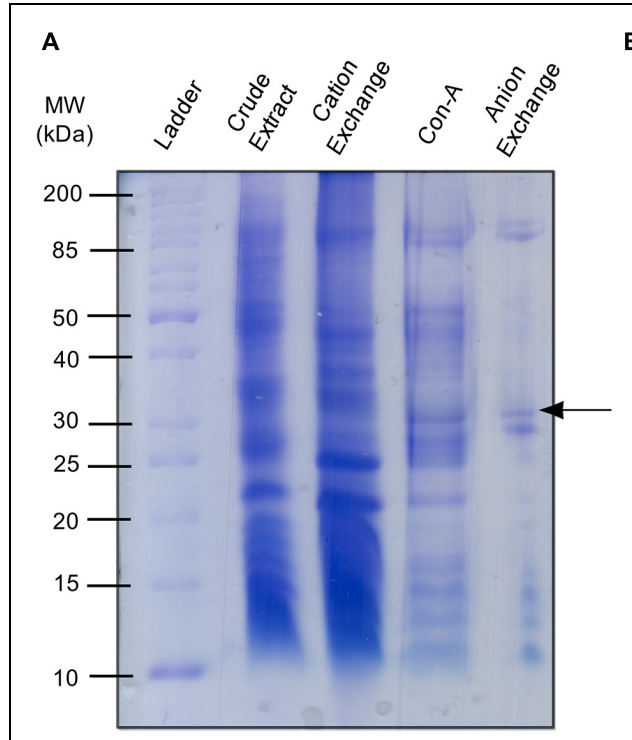

B

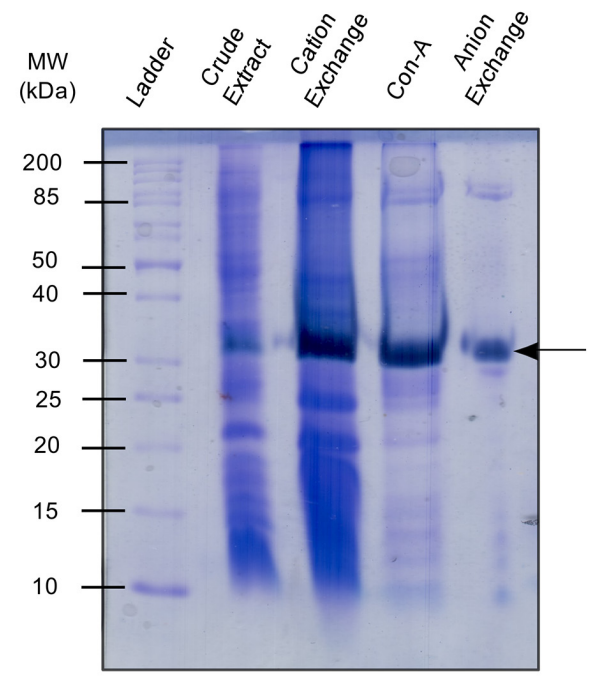

C

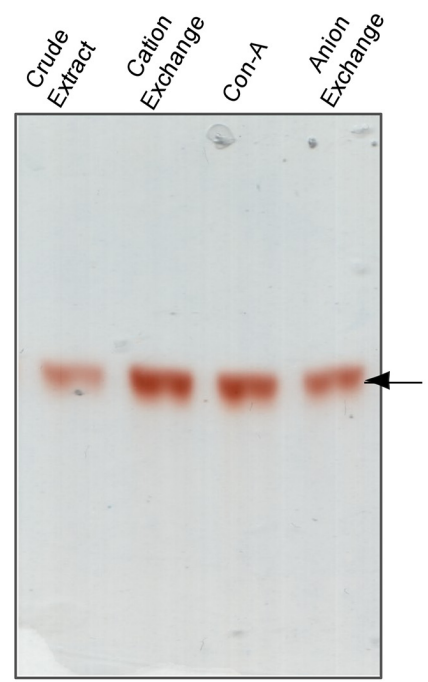

FIGURE 2 | Purification of protein with POD activity from p84C3 maize kernels. (A) Coomassie R-250 staining of the POD fractions of the different purification steps. (B) Sequential staining of POD fractions (guaiacol- $\mathrm{H}_{2} \mathrm{O}_{2}+$ Coomassie R-250). (C) Guaiacol staining of the same fractions. In all cases, $20 \mu \mathrm{L}$ of protein of the indicated fraction was loaded on each lane. Arrows indicate bands with POD

activity.

TABLE 3 | Identification of proteins from semi-purified fraction in 1D gel band with peroxidase activity, using nanoESI-LC-MS/MS (Data analysis with PeptideShaker).

\begin{tabular}{|c|c|c|c|c|c|c|c|}
\hline Hit & Protein Group & Inference Class & Description & $\begin{array}{l}\text { Sequence } \\
\text { Coverage [\%] }\end{array}$ & $\begin{array}{l}\text { \#Validated } \\
\text { Peptides }\end{array}$ & $\begin{array}{l}\text { \#Validated } \\
\text { Spectra }\end{array}$ & $\begin{array}{l}\text { Theoretical } \\
\text { MW [kDa] }\end{array}$ \\
\hline 1 & B4G1C2 & Single protein & Uncharacterized protein & 66.99 & 24 & 473 & 34.21 \\
\hline 2 & K7TID5 & Single protein & Peroxidase $^{1}$ & 42.77 & 13 & 25 & 36.77 \\
\hline 3 & B6T173 & Single protein & Peroxidase $^{1}$ & 53.98 & 13 & 26 & 36.8 \\
\hline 4 & B4G1D7 & Single protein & Uncharacterized protein & 29.13 & 7 & 18 & 38.8 \\
\hline 5 & B8QV73 & Single protein & Chtinase & 52.3 & 8 & 38 & 29.27 \\
\hline 6 & B6SGT3 & Single protein & Xylanase Inhibitor protein ${ }^{1}$ & 35.71 & 11 & 82 & 33.1 \\
\hline 7 & B8QV49 & Single protein & Chtinase & 42.86 & 6 & 26 & 28.8 \\
\hline
\end{tabular}

${ }^{1}$ Evaluated by BLASTP.

some cases, recombinant versions of PODs are susceptible to bacterial oxidative stress, by a peroxide-mediated inactivation process (Arnao et al., 1990), resulting in a recombinant nonactive version of the enzyme. Since we could not verify the POD activity of B4FFK9, we decided to track down other POD candidates by an activity-directed purification strategy.

\section{Partial Purification of Peroxidases and 1D-GE/ NanoLC-MSMS Identification}

Activity-directed partial purification of the most active POD from p84C3 seeds revealed a rarefied, yet highly active, protein (Figure 2). The apparent MW of the semi-purified enzyme is congruent with the spot location of the POD active protein in the $2 \mathrm{D}$ analysis.

In subsequent 1D-GE/nanoLC-MSMS analyses we identified various protein candidates (see Table 3 ). The proteins B6T173_MAIZE and K7TID5_MAIZE are predicted as PODs in the UniProtKB database, although no experimental evidence for their existence on protein level was reported (Magrane and Consortium, 2011). The location of spot is congruent with the molecular weight of the protein, but the apparent pI of the purified POD is more basic than the predicted value for B6T173. We contribute this pI shift to the posttranslational modification with the Fe-containing cofactor and glycosylation.

Apart from these highly probable POD candidates, we found two chitinases (B8QV73_MAIZE and B8QV49_MAIZE) and a xylanase inhibitor (B6SGT3_MAIZE) in the fraction. Two uncharacterized proteins (B4G1C2_MAIZE and B4G1D7_MAIZE) we excluded as possible PODs after a sequence analysis and domain predictions.

The peptidic sequences of the POD candidates B6T173_MAIZE and K7TID5_MAIZE only differ in ten amino acid residues, as shown in Figure $\mathbf{3 A}$, which could suggest the presence of isoforms of the enzyme. B6T173_ 


\section{A}

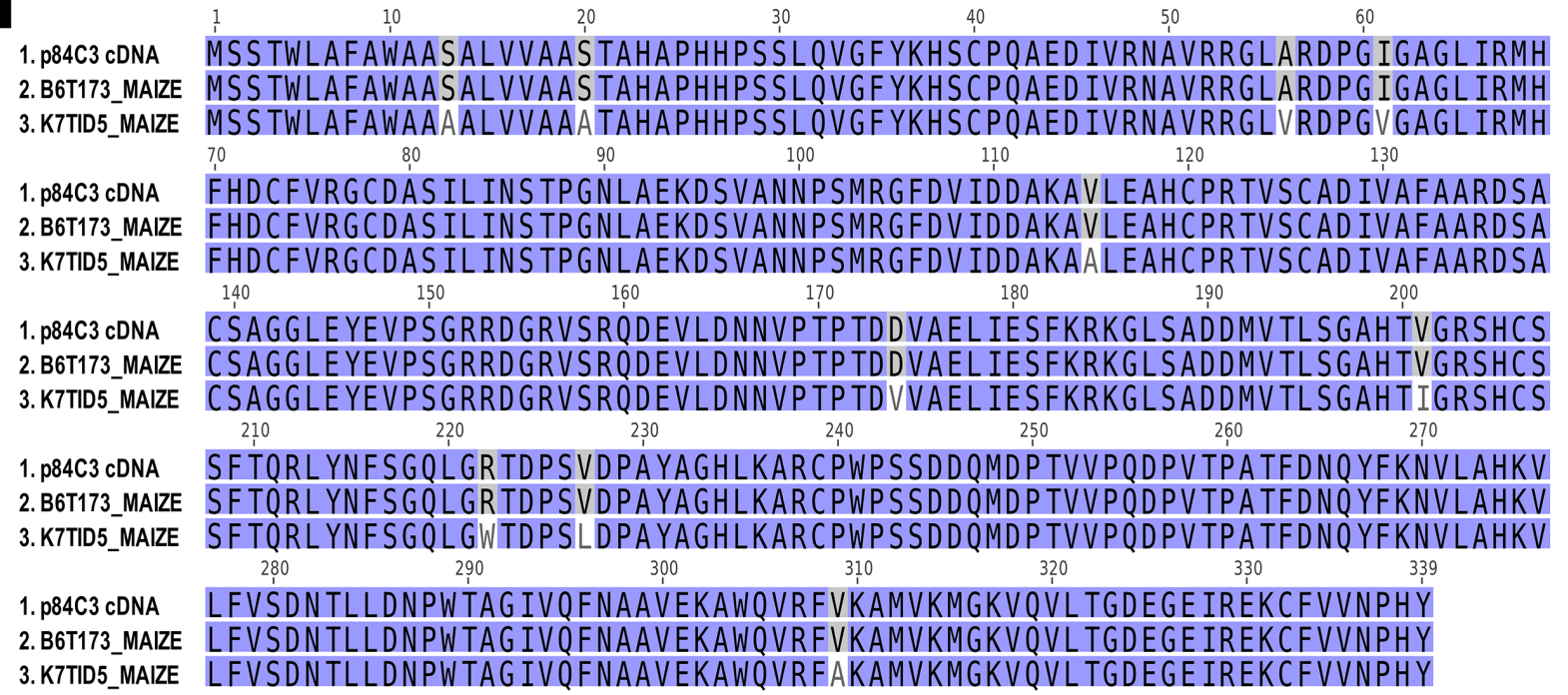

\section{B}

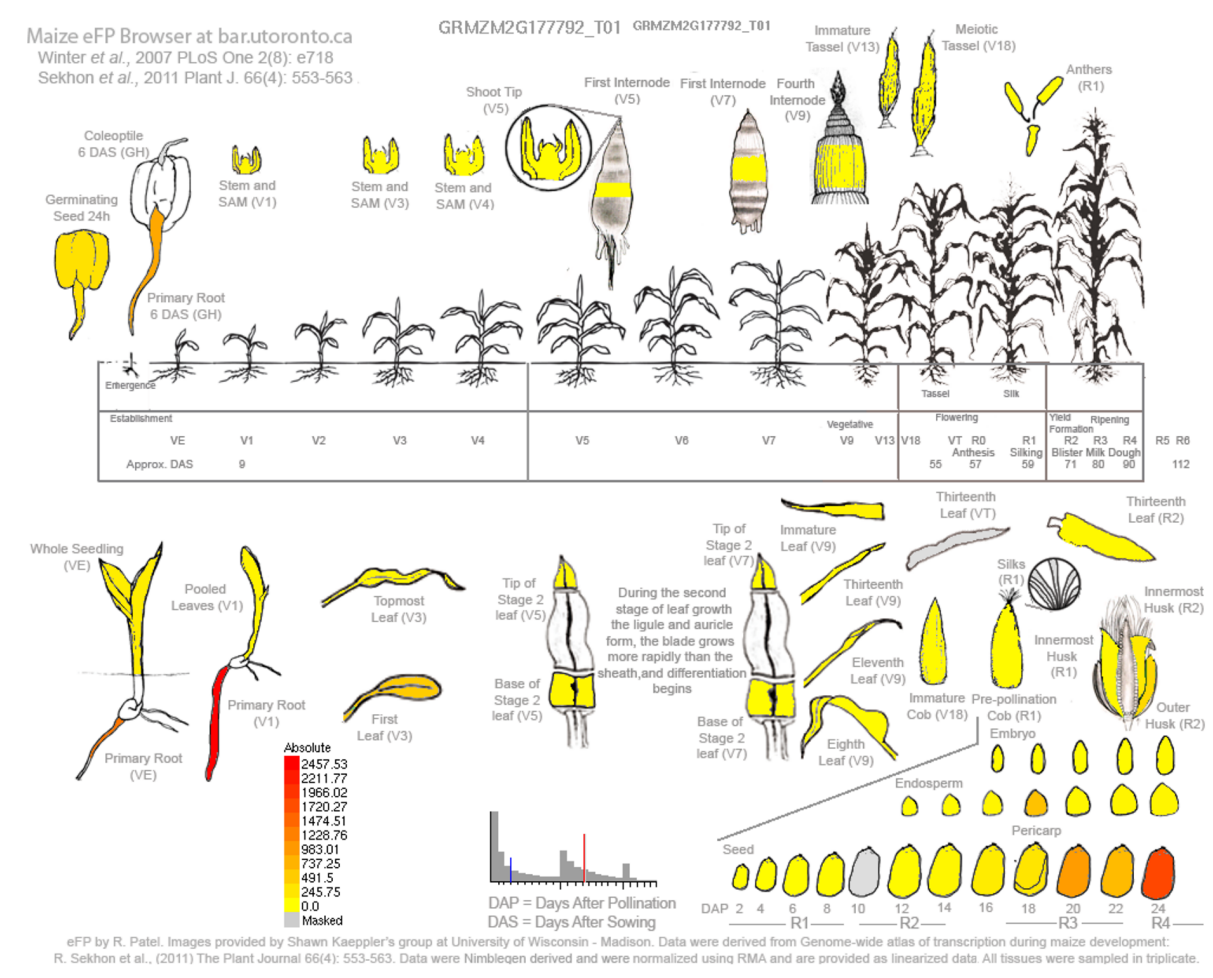

FIGURE 3/Identification and expression patterns of the POD isolated from cDNA. (A) Alignment showing the similarity of the gene product isolated from the CDNA of p84C3 maize kernels with the two putative candidates: B6T173_MAIZE and
K7TID5_MAIZE. (B) Expression patterns of the accession GRMZM2G177792_T01 accession in B73 maize (corresponding to B6T173_MAIZE UniProt accession) using the Maize eFP Browser (http://www.bar.utoronto.ca/).
MAIZE corresponds to the accession GRMZM2G177792_T01 in the maize sequence database ${ }^{10}$ and to the PeroxiBase entry

${ }^{10} \mathrm{http}: / /$ www.maizesequence.org
ZmPrx35, which has been predicted as a Class III POD (Fawal et al., 2013; Wang et al., 2015). For K7TID5_MAIZE we found no further information in publicly accessible databases or literature. 

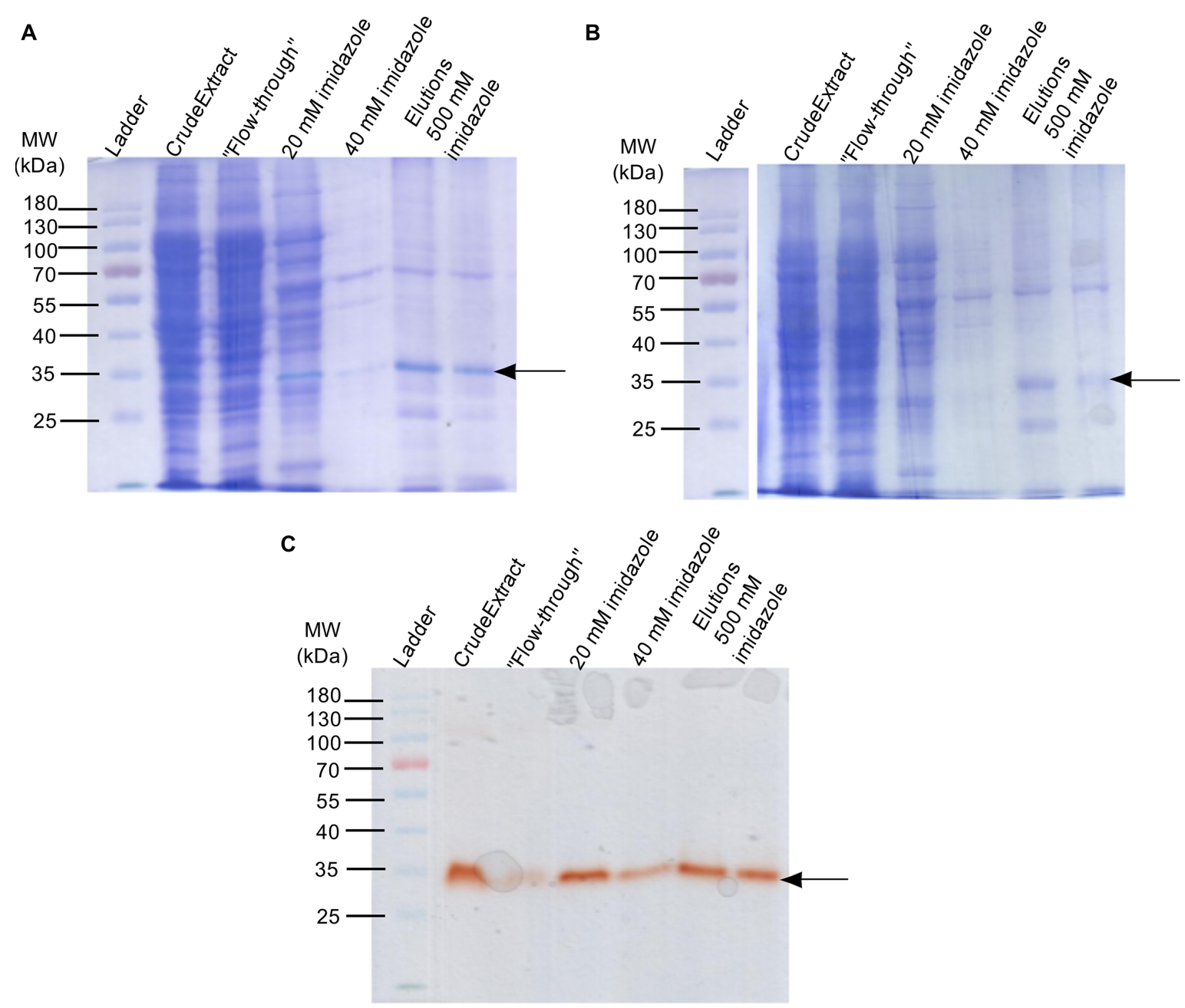

FIGURE 4 | Production and purification of the recombinant B6T173 (ZmPrx35) protein in E. coli (using the vector pET19b). (A) Sequential staining (guaiacol- $\mathrm{H}_{2} \mathrm{O}_{2}+$ Coomassie R-250) of the POD fractions obtained by
IMAC affinity purification. (B) Coomassie R-250 staining of the POD active fractions. (C) Guaiacol- $\mathrm{H}_{2} \mathrm{O}_{2}$ staining of the same POD fractions. In all cases, $20 \mu \mathrm{L}$ of protein solution were loaded. Arrows indicate bands with POD activity.

TABLE 4 | Verification of identity of recombinant B6T173 (ZmPrx35) by nanoESI-LC-MS/MS (Data analysis with PeptideShaker).

\begin{tabular}{|c|c|c|c|c|c|c|c|}
\hline Hit & Protein group & Inference class & Description & $\begin{array}{l}\text { Sequence } \\
\text { coverage } \\
{[\%]}\end{array}$ & $\begin{array}{l}\text { \#Validated } \\
\text { peptides }\end{array}$ & $\begin{array}{l}\text { \#Validated } \\
\text { spectra }\end{array}$ & $\begin{array}{l}\text { Theoretical } \\
\text { MW [kDa] }\end{array}$ \\
\hline 1 & B6T173 & Single protein & Peroxidase (Zea mays) & 19.17 & 6 & 8 & 36.8 \\
\hline 2 & C6EEI6 $^{1}$ & Single protein & Predicted DNA (exogenous) processing protein & 12.14 & 3 & 5 & 31.92 \\
\hline 3 & C6EL61 ${ }^{1}$ & Single protein & Phosphoenolpyruvate-protein phosphotransferase & 1.91 & 1 & 1 & 63.49 \\
\hline 4 & C6EK201 & Single protein & Rnase III & 5.31 & 1 & 2 & 25.53 \\
\hline 5 & C6EG51 ${ }^{1}$ & Single protein & D-ribose transporter subunit & 10.47 & 1 & 2 & 30.92 \\
\hline 6 & $\mathrm{C} 6 \mathrm{~EB}^{6} 6^{1}$ & Single protein & 6-phosphogluconate dehydrogenase, decarboxylating & 2.49 & 1 & 1 & 51.46 \\
\hline 7 & $\mathrm{C} 6 \mathrm{EKH} 4^{1}$ & Single protein & Inositol monophosphatase & 4.87 & 1 & 1 & 29.15 \\
\hline
\end{tabular}

${ }^{1}$ Escherichia coli host protein.

\section{Identification of B6T173 from Z. mays p83C3 cDNA}

Since both possible POD candidates B6T173_MAIZE and K7TID5_MAIZE share an identical N- and C-terminal region in the amino acid sequence (Figure 3A), we designed primers to amplify the actual gene from $Z$. mays p84C3 cDNA. Sequencing of the PCR product revealed $100 \%$ amino acid sequence homology with the B6T173 protein. 


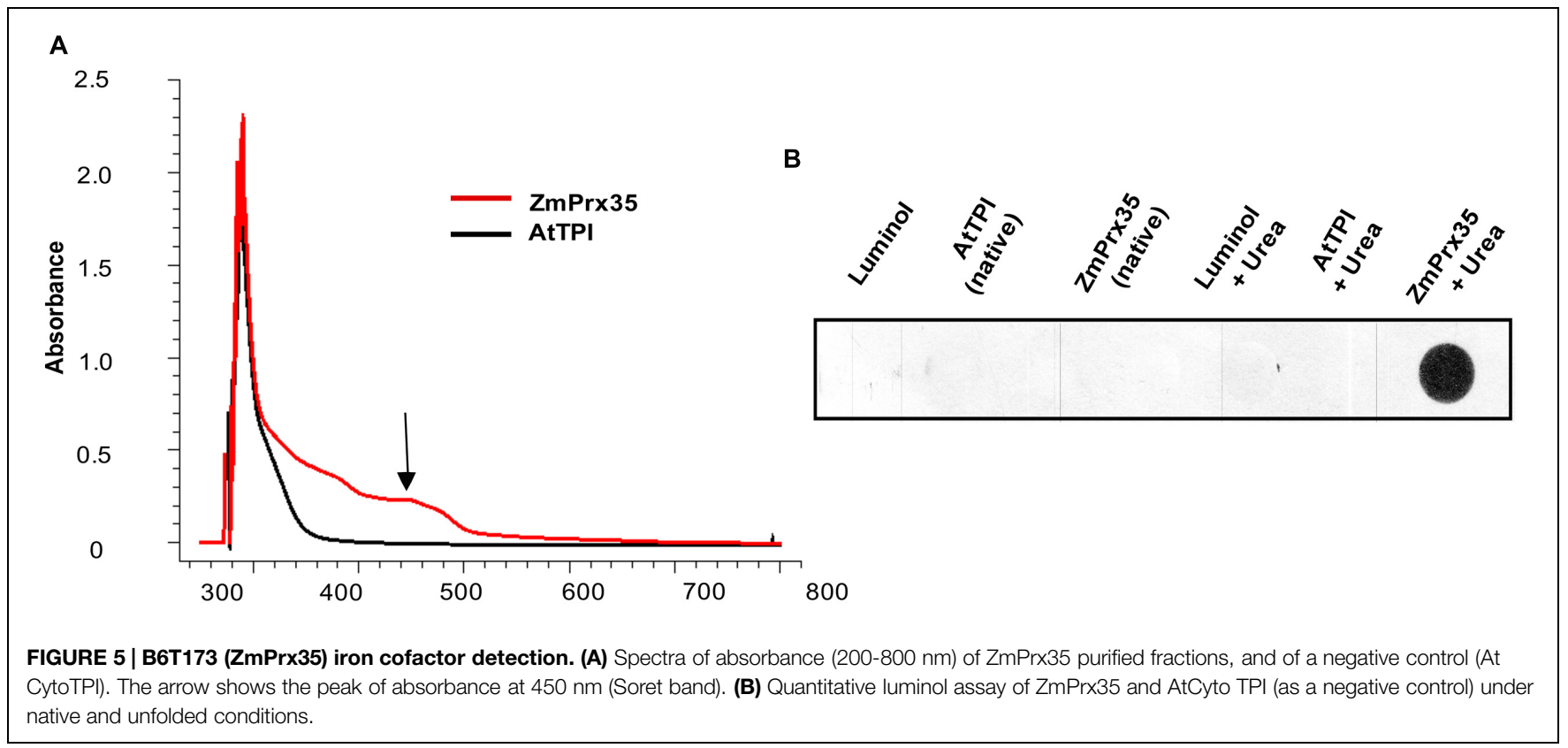

\section{In Vitro Production of B6T173 (ZmPrx35) in E. coli and Confirmation of Activity, Identity, and Haem Cofactor}

With the expression of the cloned p84C3 cDNA B6T173 amplification product, we were able to obtain recombinant and active protein, by using the pET19b, pET28b, and pMALc5x vectors (Supplementary Figure S4). The construct using the pET19b vector exhibited more activity than the other constructs (Supplementary Figure S4A). Expression of codon-optimized B6T173, cloned into the pET32a vector resulted in abundant but inactive protein product. The loss of function in the pET32a construct could be due to misfolding or an inhibition of the POD by the co-expressed thioredoxin.

The recombinant active protein obtained from the pET19b construct expression has an approximate MW of $34 \mathrm{kDa}$, which is congruent with the B6T173 amino acid sequence (Figure 4). NanoLC-MS/MS based identification verified the presence of B6T173_MAIZE (ZmPrx35) in the band with POD activity from the 1D gel with semi-purified fractions of recombinant E. coli production (see Table 4). Since no POD activity is detected in non-induced cultures (Supplementary Figure S4A), the results provide strong evidence for the heterologous production of active ZmPrx35 POD. The presence of activity after production in a bacterial host suggests that B6T173_MAIZE activity is independent from glycosylation. Similar findings were reported for the soybean cytosolic ascorbate POD (Dalton et al., 1996) and catalase (Ray et al., 2012).

UV-VIS spectra of recombinant ZmPrx35 showed increased absorbance with a maximum at about $450 \mathrm{~nm}$ (Figure 5A), which corresponds to a Soret-band feature. Thus, the spectroscopic data indicate the presence a haem group, which is a main structural characteristic of PODs (Dalton et al., 1996; Shannon et al., 1966) and related haem-dependent redox proteins such as catalase (Ray et al., 2012).
Surprisingly, no iron - the central bio-metal of the haem cofactor - was detected in ZmPrx35 protein under native conditions, using the luminol assay (Figure 5B). However, after denaturing the protein with $8 \mathrm{M}$ urea, the test was positive (Figure 5B), confirming the completeness of the POD haem cofactor.

We created a structural model of ZmPrx35 using the I-TASSER server (Supplementary Figure S3) (Yang et al., 2014). Most of the twenty-six residues predicted coordinate the haem group point toward the inside of the protein, and only a defined small channel allows entry to the active center harboring the haem group. The model is similar to other known structures of PODs (Østergaard et al., 2000; Watanabe et al., 2010). Thus, the experimental and the structural modeling results are congruent and indicate a hidden iron cofactor of the enzyme.

\section{Expression Profile Analysis}

The transcript of GRMZM2G177792_T01 (corresponding to B6T173 protein) demonstrates a high abundance of the transcript in the last stages of the seed development, as well as in the primary root during the first stages of the development of the seedling (Figure 3B). The expression profile suggests a specialized function of the POD during seed dormancy and early plant development. Searching the EnsemblePlant database ${ }^{11}$, 67 orthologs and 45 paralogs of B6T173 can be identified in various cereals. In Sorghum bicolor, the ortholog gene Sb09g002830 displays $82 \%$ identity, the corresponding gene Si $25196 \mathrm{~m} . \mathrm{g}$ in Setaria italica $81 \%$ identity. In none of the genes, the biological role has been confirmed, and only some of them have been predicted as possible PODs.

\footnotetext{
${ }^{11}$ http://plants.ensembl.org/
} 


\section{Function of B6T173 (ZmPrx35) in Insect-Resistant Maize Kernels}

To date there are few reports about PODs in maize. POD 1 and POD 70 (from corn roots) have been correlated with removal of $\mathrm{H}_{2} \mathrm{O}_{2}$, oxidation of toxic reductants, biosynthesis and degradation of lignin, suberization, auxin catabolism, response to environmental stresses such as wounding, pathogen attack and oxidative stress. These functions might depend on different isozymes/isoforms in disctinct plant tissues (Hiraga et al., 2001).

Seed PODs have been associated with various functions. Some of them are involved in the germination process, such as the barley POD isozymes (Laugesen et al., 2007) and the rice OsAPX1 (Kim et al., 2015).

A current study suggests that cross-linking of cell-wall polymers through ester-linked diferulates has a key role in plant resistance to corn borers, which is mainly due to kernel toughness rather than the indigestibility of the cell wall compounds (BarrosRios et al., 2015). The main two enzyme classes of enzymes which are involved in this polymerization mechanism are polyphenol oxidases and PODs (García-Lara et al., 2004; Lattanzio et al., 2006; Barros-Rios et al., 2015). PODs catalyze the oxidative coupling of feruloyl polysaccharides and thus increase the firmness of the cell wall, especially in the presence of reactive oxygen species (ROS; Fry et al., 2000). This function has been suggested for other seed PODs, as the soybean anionic POD SP4.1 (Gillikin and Graham, 1991).

Thus, the observed positive correlation of endosperm POD activity with maize weevil resistance for maize populations (García-Lara et al., 2007b) could be attributed to a mechanical protection of the seed, which in turn is mediated by oxidative cross-linking reactions, catalyzed by PODs. Surprisingly, a single POD, B6T173 (ZmPrx35), seems to be responsible for the high insect resistance of p84C3 maize seeds.

\section{References}

Abeles, F. B., Dunn, L. J., Morgens, P., Callahan, A., Dinterman, R. E., and Schmidt, J. (1988). Induction of 33-kD and 60-kD Peroxidases during EthyleneInduced Senescence of Cucumber Cotyledons. Plant Physiol. 87, 609-615. doi: 10.1104/pp.87.3.609

Altschul, S. F., Madden, T. L., Schäffer, A. A., Zhang, J., Zhang, Z., Miller, W., et al. (1997). Gapped BLAST and PSI-BLAST: a new generation of protein database search programs. Nucleic Acids Res. 25, 3389-3402. doi: 10.1093/nar/25.17.3389

Amaya, I., Botella, M. A., de la Calle, M., Medina, M. I., Heredia, A., Bressan, R. A., et al. (1999). Improved germination under osmotic stress of tobacco plants overexpressing a cell wall peroxidase. FEBS Lett. 457, 80-84. doi: 10.1016/S0014-5793(99)01011-X

Arnao, M. B., Acosta, M., del Río, J. A., Varón, R., and García-Cánovas, F. (1990). A kinetic study on the suicide inactivation of peroxidase by hydrogen peroxide. Biochim. Biophys. Acta 1041, 43-47. doi: 10.1016/0167-4838(90)90120-5

Barros-Rios, J., Santiago, R., Jung, H.-J. G., and Malvar, R. A. (2015). Covalent cross-linking of cell-wall polysaccharides through esterified diferulates as a maize resistance mechanism against corn borers. J. Agric. Food Chem. 63, 2206-2214. doi: 10.1021/jf505341d

Barsnes, H., Vaudel, M., Colaert, N., Helsens, K., Sickmann, A., Berven, F. S., et al. (2011). Compomics-utilities: an open-source Java library for computational proteomics. BMC Bioinformatics 12:70. doi: 10.1186/1471-2105-12-70

Bergvinson, D. J. (2001). "Storage pest resistance in maize," in Maize Research Highlights 1999-2000 (Mexico City, Mexico: CIMMYT - The Maize Program), 32-39.

\section{Conclusion}

We identified and characterized the class III POD B6T173 (ZmPrx35), which accounts for about $80 \%$ of the POD activity in maize ( $Z$. mays $\mathrm{p} 84 \mathrm{C} 3$ ) kernels. The positive correlation between POD activity and post-harvest insect resistance suggests the use of ZmPrx35 as biomarker and for genetic engineering of maize.

Considering possible mechanisms of resistance and enzyme functions, ZmPrx35 is likely to be involved in the cell-wall strengthening by oxidative coupling of feruloyl polysaccharides. The expression pattern of the respective gene transcript indicates an additional role in the seedling development.

Despite their physiological relevance, only few plant PODs have been studied on protein level up to now. Therefore, to account for the low abundance of these enzymes we recommend an activity-directed proteomics strategy.

\section{Acknowledgments}

We cordially thank Alicia Chagolla of the Proteomics service lab (CINVESTAV Unidad Irapuato) for excellent technical assistance and Diana Rossetti (Peace Corps) for proof-reading the manuscript. The study was funded by the CONACYT basic science grant I0017/CB-2010-01/151596, FINNOVA I010/260/2014 and the CINVESTAV. LL-C and JL-A thank for their CONACYT scholarships.

\section{Supplementary Material}

The Supplementary Material for this article can be found online at: http://journal.frontiersin.org/article/10.3389/fpls.2015.00670

Bergvinson, D., and García-Lara, S. (2004). Genetic approaches to reducing losses of stored grain to insects and diseases. Curr. Opin. Plant Biol. 7, 480-485. doi: 10.1016/j.pbi.2004.05.001

Bjellqvist, B., Ek, K., Righetti, P. G., Gianazza, E., Görg, A., Westermeier, R., et al. (1982). Isoelectric focusing in immobilized $\mathrm{pH}$ gradients: principle, methodology and some applications. J. Biochem. Biophys. Methods 6, 317-339. doi: 10.1016/0165-022X(82)90013-6.

Chambers, M. C., Maclean, B., Burke, R., Amodei, D., Ruderman, D. L., Neumann, S., et al. (2012). A cross-platform toolkit for mass spectrometry and proteomics. Nat. Biotechnol. 30, 918-920. doi: 10.1038/nbt.2377

Craig, R., and Beavis, R. C. (2004). TANDEM: matching proteins with tandem mass spectra. Bioinformatics 20, 1466-1467. doi: 10.1093/bioinformatics/bth092

Dales, M. J., and Golob, P. (1997). The protection of maize against Prostephanus truncatus (Horn), using insecticide sprays in Tanzania. Int. J. Pest Manag. 43, 39-43. doi: 10.1080/096708797228960

Dalton, D. A., Diaz del Castillo, L., Kahn, M. L., Joyner, S. L., and Chatfield, J. M. (1996). Heterologous expression and characterization of soybean cytosolic ascorbate peroxidase. Arch. Biochem. Biophys. 328, 1-8. doi: 10.1006/abbi.1996.0135

Deutsch, E. W., Mendoza, L., Shteynberg, D., Slagel, J., Sun, Z., and Moritz, R. L. (2015). Trans-Proteomic Pipeline, a standardized data processing pipeline for large-scale reproducible proteomics informatics. Proteomics Clin. Appl. 9, 745-754. doi: 10.1002/prca.201400164

Elias, J. E., and Gygi, S. P. (2007). Target-decoy search strategy for increased confidence in large-scale protein identifications by mass spectrometry. Nat. Methods 4, 207-214. doi: 10.1038/nmeth1019 
Fawal, N., Li, Q., Savelli, B., Brette, M., Passaia, G., Fabre, M., et al. (2013). PeroxiBase: a database for large-scale evolutionary analysis of peroxidases. Nucleic Acids Res. 41, 441-444. doi: 10.1093/nar/gks1083

Fleischmann, A., Darsow, M., Degtyarenko, K., Fleischmann, W., Boyce, S., Axelsen, K. B., et al. (2004). IntEnz, the integrated relational enzyme database. Nucleic Acids Res. 32, D434-D437. doi: 10.1093/nar/gkh119

Francoz, E., Ranocha, P., Nguyen-Kim, H., Jamet, E., Burlat, V., and Dunand, C. (2015). Roles of cell wall peroxidases in plant development. Phytochemistry 112, 15-21. doi: 10.1016/j.phytochem.2014.07.020

Fry, S. C., Willis, S. C., and Paterson, A. E. (2000). Intraprotoplasmic and wall-localised formation of arabinoxylan-bound diferulates and larger ferulate coupling-products in maize cell-suspension cultures. Planta 211, 679-692. doi: 10.1007/s004250000330

García-Lara, S., Arnason, J. T., Díaz-Pontones, D., Gonzalez, E., and Bergvinson, D. J. (2007a). Soluble peroxidase activity in maize endosperm associated with maize weevil resistance. Crop Sci. 47, 1125. doi: 10.2135/cropsci2006.10.0687

García-Lara, S., Arnason, J. T., Díaz-Pontones, D., Gonzalez, E., and Bergvinson, D. J. (2007b). Soluble peroxidase activity in maize endosperm associated with maize weevil resistance. Crop Sci. 47, 1125-1130. doi: 10.2135/cropsci2006.10.0687

García-Lara, S., Bergvinson, D. J., Burt, A. J., Ramputh, A. I., Díaz-Pontones, D. M., and Arnason, J. T. (2004). The role of pericarp cell wall components in maize weevil resistance. Crop Sci. 44, 1546-1552. doi: 10.2135/cropsci2004.1546

García-Lara, S., Ortíz-Islas, S., and Villers, P. (2013). Portable hermetic storage bag resistant to Prostephanus truncatus, Rhyzopertha dominica, and Callosobruchus maculatus. J. Stored Prod. Res. 54, 23-25. doi: 10.1016/j.jspr.2013.04.001.

Geer, L. Y., Markey, S. P., Kowalak, J. A., Wagner, L., Xu, M., Maynard, D. M., et al. (2004). Open mass spectrometry search algorithm research articles. J. Proteome Res. 3, 958-964. doi: 10.1021/pr0499491

Gillikin, J. W., and Graham, J. S. (1991). Purification and developmental analysis of the major anionic peroxidase from the seed coat of Glycine max. Plant Physiol. 96, 214-220. doi: 10.1104/pp.96.1.214

González-Rábade, N., Del Carmen Oliver-Salvador, M., Salgado-Manjarrez, E., and Badillo-Corona, J. A. (2012). In vitro production of plant peroxidases-a review. Appl. Biochem. Biotechnol. 166, 1644-1660. doi: 10.1007/s12010-0129558-2

Gupta, R., Wang, Y., Agrawal, G. K., Rakwal, R., Jo, I. H., Bang, K. H., et al. (2015). Time to dig deep into the plant proteome: a hunt for low-abundance proteins. Front. Plant Sci. 6:22. doi: 10.3389/fpls.2015.00022.

Heckman, K. L., and Pease, L. R. (2007). Gene splicing and mutagenesis by PCRdriven overlap extension. Nat. Protoc. 2, 924-932. doi: 10.1038/nprot.2007.132

Hiraga, S., Sasaki, K., Ito, H., Ohashi, Y., and Matsui, H. (2001). A large family of class III plant peroxidases. Plant Cell Physiol. 42, 462-468. doi: 10.1093/pcp/pce061

Högbom, M., Ericsson, U. B., Lam, R., Bakali H, M. A., Kuznetsova, E., Nordlund, P., et al. (2005). A high throughput method for the detection of metalloproteins on a microgram scale. Mol. Cell. Proteomics 4, 827-834. doi: 10.1074/mcp.T400023-MCP200

Keller, A., Nesvizhskii, A. I., Kolker, E., and Aebersold, R. (2002). Empirical statistical model to estimate the accuracy of peptide identifications made by MS/MS and database search. Anal. Chem. 74, 5383-5392. doi: 10.1021/ac025747h

Kim, Y. J., Kim, S., Kesavan, M., Kwak, J. S., Song, J. T., and Seo, H. S. (2015). Ascorbate peroxidase OsAPx1 is involved in seed development in rice. Plant Breed Biotech. 2015, 11-20. doi: 10.9787/PBB.2015.3.1.011

Lagrimini, L. M., Joly, R. J., Dunlap, J. R., and Liu, T. T. (1997). The consequence of peroxidase overexpression in transgenic plants on root growth and development. Plant Mol. Biol. 33, 887-895. doi: 10.1023/A:10057567 13493

Lattanzio, V., Lattanzio, V. M. T., Cardinali, A., and Amendola, V. (2006). "Role ofphenolics in the resistance mechanisms of plants against fungal pathogens and insects," in Phytochemistry: Advancesin Research, ed. F. Imperato (Trivandrum, India: Research Signpost), 23-67.

Laugesen, S., Bak-Jensen, K. S., Hgglund, P., Henriksen, A., Finnie, C., Svensson, B., et al. (2007). Barley peroxidase isozymes: expression and posttranslational modification in mature seeds as identified by two-dimensional gel electrophoresis and mass spectrometry. Int. J. Mass Spectrom. 268, 244-253. doi: 10.1016/j.ijms.2007.06.003
Magrane, M., and Consortium, U. (2011). UniProt Knowledgebase: a hub of integrated protein data. Database (Oxford) 2011, bar009. doi: 10.1093/database/bar009

Mata-Gómez, M. A., Yasui, M. T., Guerrero-Rangel, A., Valdés-Rodríguez, S., and Winkler, R. (2012). Accelerated identification of proteins by mass spectrometry by employing covalent pre-gel staining with Uniblue A. PLoS ONE 7:e31438. doi: 10.1371/journal.pone.0031438

Mika, A., and Lüthje, S. (2003). Properties of guaiacol peroxidase activities isolated from corn root plasma membranes. Plant Physiol. 132, 1489-1498. doi: 10.1104/pp.103.020396

Nesvizhskii, A. I., Keller, A., Kolker, E., and Aebersold, R. (2003). A statistical model for identifying proteins by tandem mass spectrometry. Anal. Chem. 75, 4646-4658. doi: 10.1021/ac0341261

Østergaard, L., Teilum, K., Mirza, O., Mattsson, O., Petersen, M., Welinder, K. G., et al. (2000). Arabidopsis ATP A2 peroxidase. Expression and high-resolution structure of a plant peroxidase with implications for lignification. Plant Mol. Biol. 44, 231-243. doi: 10.1023/A:1006442618860

Pedlowski, M. A., Canela, M. C., da Costa Terra, M. A., and Ramos de Faria, R. M. (2012). Modes of pesticides utilization by Brazilian smallholders and their implications for human health and the environment. Crop Prot. 31, 113-118. doi: 10.1016/j.cropro.2011.10.002

Pingali, P. L., and Pandey, S. (2001). "Meeting world maize needs: technological opportunities and priorities for the public sector," in CIMMYT 1999-2000 World Maize Facts and Trends, ed. P. L. Pingali (Mexico City, Mexico: CIMMYT), 1-24.

Rauch, A., Bellew, M., Eng, J., Fitzgibbon, M., Holzman, T., Hussey, P., et al. (2006). Computational proteomics analysis system (CPAS): an extensible, opensource analytic system for evaluating and publishing proteomic data and high throughput biological experiments. J. Proteome Res. 5, 112-121. doi: $10.1021 /$ pr0503533

Ray, M., Mishra, P., Das, P., and Sabat, S. C. (2012). Expression and purification of soluble bio-active rice plant catalase-a from recombinant Escherichia coli. J. Biotechnol. 157, 12-19. doi: 10.1016/j.jbiotec.2011.09.022

Sekhon, R. S., Lin, H., Childs, K. L., Hansey, C. N., Robin Buell, C., De Leon, N., et al. (2011). Genome-wide atlas of transcription during maize development. Plant J. 66, 553-563. doi: 10.1111/j.1365-313X.2011. 04527.x

Shannon, L. M., Kay, E., and Lew, J. Y. (1966). Peroxidase isozymes from horseradish roots. I. Isolation and Physical Properties. J. Biol. Chem. 241, 2166-2172.

Shevchenko, A., Tomas, H., Havlis, J., Olsen, J. V., and Mann, M. (2006). In-gel digestion for mass spectrometric characterization of proteins and proteomes. Nat. Protoc. 1, 2856-2860. doi: 10.1038/nprot.2006.468

Shevchenko, A., Wilm, M., Vorm, O., and Mann, M. (1996). Mass spectrometric sequencing of proteins silver-stained polyacrylamide gels. Anal. Chem. 68, 850-858. doi: 10.1021/ac950914h

Tefera, T., Kanampiu, F., De Groote, H., Hellin, J., Mugo, S., Kimenju, S., et al. (2011). The metal silo: an effective grain storage technology for reducing post-harvest insect and pathogen losses in maize while improving smallholder farmers' food security in developing countries. Crop Prot. 30, 240-245. doi: 10.1016/j.cropro.2010.11.015

Vaudel, M., Barsnes, H., Berven, F. S., Sickmann, A., and Martens, L. (2011). SearchGUI: an open-source graphical user interface for simultaneous OMSSA and X!Tandem searches. Proteomics 11, 996-999. doi: 10.1002/pmic.2010 00595

Vizcaíno, J. A., Deutsch, E. W., Wang, R., Csordas, A., Reisinger, F., Ríos, D., et al. (2014). ProteomeXchange provides globally coordinated proteomics data submission and dissemination. Nat. Biotechnol. 32, 223-226. doi: $10.1038 /$ nbt.2839

Wang, G., Wang, G., Zhang, X., Wang, F., and Song, R. (2012). Isolation of high quality RNA from cereal seeds containing high levels of starch. Phytochem. Anal. 23, 159-163. doi: 10.1002/pca.1337

Wang, Y., Wang, Q., Zhao, Y., Han, G., and Zhu, S. (2015). Systematic analysis of maize class III peroxidase gene family reveals a conserved subfamily involved in abiotic stress response. Gene doi: 10.1016/j.gene.2015. 04.041

Watanabe, L., de Moura, P. R., Bleicher, L., Nascimento, A. S., Zamorano, L. S., Calvete, J. J., et al. (2010). Crystal structure and statistical coupling analysis of 
highly glycosylated peroxidase from royal palm tree (Roystonea regia). J. Struct. Biol. 169, 226-242. doi: 10.1016/j.jsb.2009.10.009

Whetten, R. W., MacKay, J. J., and Sederoff, R. R. (1998). Recent advances in understanding lignin biosynthesis. Annu. Rev. Plant Physiol. Plant Mol. Biol. 49, 585-609. doi: 10.1146/annurev.arplant.49.1.585

Winkler, R. (2014). MASSyPup - an "Out of the Box" solution for the analysis of mass spectrometry data. J. Mass Spectrom. 49, 37-42. doi: 10.1002/jms. 3314

Winkler, R., and García-Lara, S. (2010). Activity-directed identification of maize kernel peroxidases associated with postharvest insect resistance. Mol. Biosyst. 6, 1810-1812. doi: $10.1039 / \mathrm{c} 003112 \mathrm{~g}$

Winter, D., Vinegar, B., Nahal, H., Ammar, R., Wilson, G. V., and Provart, N. J. (2007). An "Electronic Fluorescent Pictograph" Browser for Exploring and Analyzing Large-Scale Biological Data Sets. PLOS ONE 2:e718. doi: 10.1371/journal.pone.0000718
Yang, J., Yan, R., Roy, A., Xu, D., Poisson, J., and Zhang, Y. (2014). The I-TASSER Suite: protein structure and function prediction. Nat. Methods 12, 7-8. doi: 10.1038/nmeth.3213

Conflict of Interest Statement: The authors declare that the research was conducted in the absence of any commercial or financial relationships that could be construed as a potential conflict of interest.

Copyright () 2015 López-Castillo, López-Arciniega, Guerrero-Rangel, ValdésRodríguez, Brieba, García-Lara and Winkler. This is an open-access article distributed under the terms of the Creative Commons Attribution License (CC BY).

The use, distribution or reproduction in other forums is permitted, provided the original author(s) or licensor are credited and that the original publication in this journal is cited, in accordance with accepted academic practice. No use, distribution or reproduction is permitted which does not comply with these terms. 